\title{
Optimization for Scenedesmus obliquus Cultivation: the Effects of Temperature, Light Intensity and pH on Growth and Biochemical Composition
}

\author{
Yonggang Zhang ${ }^{1}$, Li Ren ${ }^{2}$, Huaqiang $\mathrm{Chu}^{2}$, Xuefei Zhou ${ }^{2}$, Tianming Yao ${ }^{1 *}$, and Yalei Zhang ${ }^{2 *}$ \\ ${ }^{1}$ School of Chemical Science and Engineering, ${ }^{2}$ State Key Laboratory of Pollution Control and Resource Reuse, Tongji University, \\ Shanghai 200092, P.R. China
}

Received: June 12, 2019 / Revised: July 23, 2019 / Accepted: July 25, 2019

\begin{abstract}
Microalgae have been explored as potential host species for biofuel production. Environmental factors affect algal growth and cellular composition. The effects of several key environmental factors, such as temperature, light, and $\mathrm{pH}$ of the medium on the growth and biochemical composition of Scenedesmus obliquus were investigated in this study. The highest growth rate of microalgae was observed at an optimal temperature of $25{ }^{\circ} \mathrm{C}, 150 \mu \mathrm{mol} /\left(\mathrm{m}^{2} \cdot \mathrm{s}\right)$ light intensity, and $\mathrm{pH} 10.0$. The biochemical composition analysis revealed that the carbohydrate content decreased at lower $\left(20^{\circ} \mathrm{C}\right)$ or higher temperature $\left(35^{\circ} \mathrm{C}\right)$, whereas the protein and lipid contents increase at these temperatures. The fluctuation of light intensity significantly affected the contents of protein, carbohydrate, and lipid. The protein levels varied greatly when the $\mathrm{pH}$ of the medium was below 7.0. The carbohydrate and lipid contents significantly increased at pH above 7.0.
\end{abstract}

Keywords: Scenedesmus obliquus, temperature, light, medium pH, growth rate, lipid content

\section{Introduction}

Due to the overconsumption of fossil fuel, the increasing demand for energy and environment pollution are major challenges facing modern society [1]. In recent years, biodiesel produced from algae biomass is receiving widespread attention owing to the potential as a non-toxic, renewable and biodegradable fuel because of the high photosynthetic efficiency and growth of algae. Moreover, microalgae have several functions for removing pollutants, contributing to the development of the

\section{*Corresponding authors}

T. Yao

Tel: +86-21-65983292, Fax: +86-21-65985811

E-mail: tmyao@tongji.edu.cn

Y. Zhang

Tel: +86-21-65983292, Fax: +86-21-65985811

E-mail: zhangyalei@tongji.edu.cn

( ) 2019, The Korean Society for Microbiology and Biotechnology coupling of bioenergy and wastewater treatment [2]. Despite these advantages, several problems remain to be addressed to make this technology competitive for commercial production of biodiesel [3-5]. Improved strains based on volumetric productivity, appropriate metabolic profile and optimal cultivation conditions are required to make feasible for large-scale production [6].

Cultivation for microalgae requires consideration of different environmental conditions. Among the several factors affecting the growth of microalgae, environmental factors such as temperature, light intensity, and $\mathrm{pH}$, may significantly affect the algal growth and cellar compositions [7-9]. Temperature plays a crucial role in algae growth and photosynthetic activity of microalgae. In the cultivation process, algae growth and lipid accumulation with different temperatures are influenced by the activity of enzyme, material exchange and cell division [10]. Due to photosynthetic characteristics, light condition is 
one of the most important factors for microalgae growth, which affects the growth rate and appreciation rate mainly through regulating intensity and time [11]. Under certain light conditions, the appropriate intensity can promote growth and accumulation of lipid in algae. The growth can be inhibited with too low or high light intensity. $\mathrm{pH}$ is believed to be one of the basic parameters affect enzyme activity and material flow and utilization in microalgae [10]. Most algal strains are known to flourish at neutral $\mathrm{pH}$ about 7.0 to 7.6, and all strains seem to have a limited optimal range of $\mathrm{pH}$.

Scenedesmus obliquus (S. obliquus) is one of the most potential species as feedstock for biodiesel production and wastewater treatment [12]. The optimization of its cultivation conditions is the key premise for bioenergy and pollutant removal researches. Microalgae at optimal temperature results in a high growth rate [13]. It was found that $S$. obliquus is mesophilic and can grow at a temperature between 15 and $40^{\circ} \mathrm{C}$. Martínez et al. have demonstrated that the highest specific growth of $S$. obliquus was obtained at $30^{\circ} \mathrm{C}$ [14]. Moreover, light intensity affects the growth of algae through its impact on photosynthesis. Previous research has reported that photosynthetic pigment was affected. It was found that protein, carbohydrate, and lipid contents remained stable with light intensity from $50-1000 \mu \mathrm{mol} /\left(\mathrm{m}^{2} \cdot \mathrm{s}\right)$ and the highest growth was detected at $150 \mu \mathrm{mol} /\left(\mathrm{m}^{2} \cdot \mathrm{s}\right)$ in $S$. obliquus $[15,16]$. A fluctuated medium $\mathrm{pH}$ may limit the growth of algae via metabolic inhibition. The optimal $\mathrm{pH}$ for growth of S. obliquus was observed under neutral and alkaline conditions, while resulting in an increase of triglyceride accumulation. The maximum growth was observed at a pH of 8.0 [17].

Whether in laboratory experiments or open ponds researches, cultivation for algae requires consideration of optimizing numerous environmental conditions. However, the optimal environmental conditions are mostly deliberated separately in different culture medium; there are few studies available which focus on the main environmental factors in the same medium synchronously. Furthermore, environmental factors not only affect photosynthesis and growth rate but also influence the activity and composition of cellular metabolites [8]. However, plenty of previous researches with environmental factors have exclusively concentrated on effects on lipid accumulation and do not examine the alteration of biochemical compositions (i.e. protein, carbohydrate, and lipid) [18-20].

In this paper, the effects of major environmental factors, including temperature, light intensity, and $\mathrm{pH}$, on S. obliquus growth and biochemical compositions were investigated. S. obliquus showed the highest growth rate with optimal conditions of temperature $25^{\circ} \mathrm{C}$, light intensity $150 \mu \mathrm{mol} /\left(\mathrm{m}^{2} \cdot \mathrm{s}\right)$ and $\mathrm{pH}$ value 10.0 . Temperature and light intensity contributed to the increase in protein and lipid. The content of protein was influenced obviously when the medium $\mathrm{pH}$ value was below 7.0, while a higher $\mathrm{pH}$ above 7.0 significantly affecting the carbohydrate and lipid contents. This study expounded the influence of both algae growth and broader biochemical process with consolidated environmental factors. These results may guide optimal system establishment and efficient scale-up of production for biodiesels and bioproducts.

\section{Materials and Methods}

\section{Microalgae strain and culturing conditions}

The microalgae strain was prepared from Freshwater Algae Culture Colletion at the Institute of Hydrobiology, in Wuhan, China. The culture medium was modified BG11 [18, 19], consisting of $\mathrm{NaNO}_{3}(1500 \mathrm{mg} / \mathrm{l}), \mathrm{K}_{2} \mathrm{HPO}_{4}$. $3 \mathrm{H}_{2} \mathrm{O}(40 \mathrm{mg} / \mathrm{l}), \mathrm{MgSO}_{4} \cdot 7 \mathrm{H}_{2} \mathrm{O}(75 \mathrm{mg} / \mathrm{l})$, ammonium ferric citrate $(6 \mathrm{mg} / \mathrm{l}), \mathrm{CaCl}_{2} \cdot 2 \mathrm{H}_{2} \mathrm{O}(36 \mathrm{mg} / \mathrm{l}), \mathrm{Na}_{2} \mathrm{CO}_{3}(20 \mathrm{mg} / \mathrm{l})$, citric acid (6 mg/l ), EDTA (1 mg/l ), $\mathrm{H}_{3} \mathrm{BO}_{3}(2.86 \mathrm{mg} / \mathrm{l})$, $\mathrm{MnCl}_{2} \cdot 4 \mathrm{H}_{2} \mathrm{O} \quad(1.81 \mathrm{mg} / \mathrm{l}), \quad \mathrm{ZnSO}_{4} \cdot 7 \mathrm{H}_{2} \mathrm{O} \quad(0.22 \mathrm{mg} / \mathrm{l})$, $\mathrm{CuSO}_{4} \cdot 5 \mathrm{H}_{2} \mathrm{O}(0.079 \mathrm{mg} / \mathrm{l}),\left(\mathrm{NH}_{4}\right) 6 \mathrm{Mo}_{7} \mathrm{O}_{24} \cdot 4 \mathrm{H}_{2} \mathrm{O}(0.39$ $\mathrm{mg} / \mathrm{l})$ and $\mathrm{Co}\left(\mathrm{NO}_{3}\right)_{2} \cdot 6 \mathrm{H}_{2} \mathrm{O}(0.049 \mathrm{mg} / \mathrm{l})$. The strain was cultivated in $500 \mathrm{ml}$ flask containing $400 \mathrm{ml}$ BG11 medium. The initial algal concentration was about $0.15 \mathrm{~g} / \mathrm{l}$ (dried weight) with shaking three times a day for 22 days. The cultivation temperatures were controlled at $20,25,30$ and $35^{\circ} \mathrm{C}$ respectively with a light intensity of $100 \mu \mathrm{mol} /\left(\mathrm{m}^{2} \cdot \mathrm{s}\right)$ and a medium $\mathrm{pH}$ value of 8.0 . The light intensities of cultivation conditions were maintained at $50,100,150$ and $200 \mu \mathrm{mol} /\left(\mathrm{m}^{2} \cdot \mathrm{s}\right)$, respectively. The temperature was controlled at $25 \pm 1{ }^{\circ} \mathrm{C}$ with an initial $\mathrm{pH}$ value of 8.0 . The medium of initial $\mathrm{pH}$ values was set at $5,6,7,8,9,10$ and 11 respectively. Illumination was provided on a $12 \mathrm{~h}$ light, $12 \mathrm{~h}$ dark cycle. All experiments were carried out in triplicate. 


\section{Estimation of biomass concentration}

The cell concentration of the culture was determined by measuring the $\mathrm{OD}_{680}$ (the optical density of algae culture at 680) using a UV spectrophotometer [11]. The dry weight of the microalgae biomass with a known volume was estimated by centrifuging at $5000 \mathrm{rpm}$ for $10 \mathrm{~min}$. The harvested biomass was dried at $105^{\circ} \mathrm{C}$ until the weight was invariant. The microalgae dry weight was obtained by subtracting the blank biomass. The $\mathrm{OD}_{680}$ value was converted to biomass concentration via appropriate calibration between $\mathrm{OD}_{680}$ and dry cell weight and the conversion factor was determined. The relationship of microalgae biomass concentration was shown in Eq. (1) (determined with the experiment result).

$$
B C=0.3625 \times \mathrm{OD}_{680}-0.0319, R^{2}=0.99587
$$

\section{Determination of protein content}

The estimation of protein content was analyzed using the Kjeldahl nitrogen determination method, the same as the national standard of the People's Republic of China (GB/T5009.5-2003). The calibration between protein content and nitrogen content was confirmed as PC $($ protein content $)=\mathrm{NC}($ nitrogen content $) \times 6.25$.

\section{Determination of carbohydrate content}

The carbohydrate content in microalgae was analyzed mainly by a modified method from Chaplin M. The carbohydrate was determined by the phenol-sulfuric acid reaction with the standard of glucose [20]. A 15-ml medium containing algae cell was centrifuged at 5000 rpm for $5 \mathrm{~min}$ and removed the supernatant. The buffer solution was then added into the biomass and the cells were broken with ultrasonic. The supernatant collected after centrifugation added a $6 \mathrm{ml}$ phenol-sulfuric acid solution and heated at $90^{\circ} \mathrm{C}$ after $15 \mathrm{~min}$. The result was determined by measuring the $\mathrm{OD}_{485}$.

\section{Determination of lipid content}

The content of lipids was done following the method of Bligh and Dyer [21]. $0.5 \mathrm{~g}$ dried algae powder was
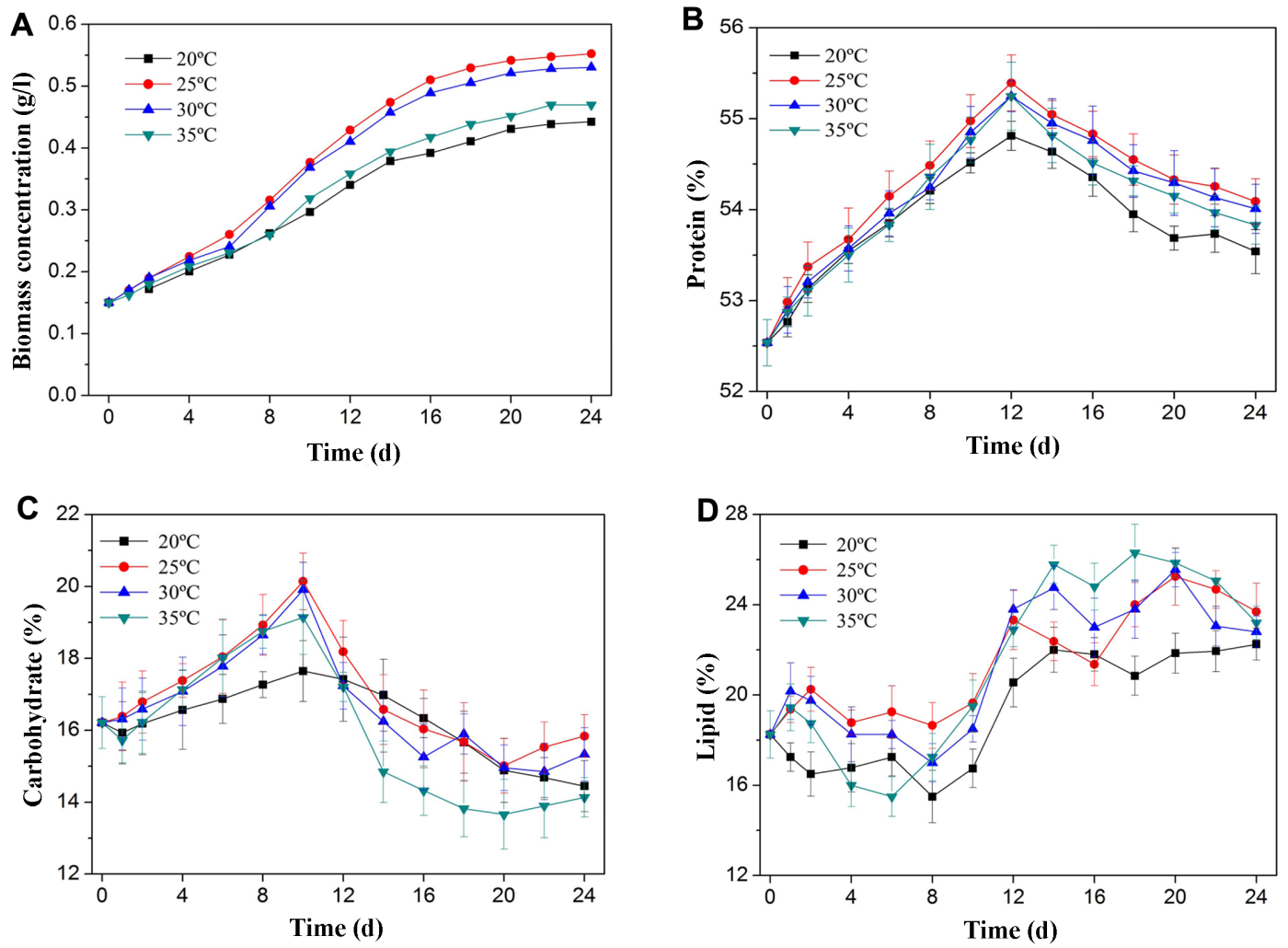

Fig. 1. The effects of temperature on growth and biochemical compositions in S. obliquus. Biomass concentration (A), protein content $(B)$, carbohydrate content $(C)$, lipid content $(D)$ under different temperature. Error bars represent standard error. 
extracted with a mixture of chloroform and methanol $(2: 1 \mathrm{v} / \mathrm{v})$ and kept for $24 \mathrm{~h}$ at $25^{\circ} \mathrm{C}$. The supernatant was separated by centrifugation for $10 \mathrm{~min}$ at $5000 \mathrm{rpm}$ and the solvent was removed using a rotary evaporator at $104^{\circ} \mathrm{C}$ for $30 \mathrm{~min}$.

\section{Results and Discussion}

\section{Effect of temperature on biomass production and bio- chemical composition of S. obliquus}

The growth curves of $S$. obliquus in a medium for cultivation with different temperature were shown in Fig.

1A. Cultivation of $S$. obliquus for 22 days grew into the stable phase. The groups of $20^{\circ} \mathrm{C}$ and $35^{\circ} \mathrm{C}$ had consistent growth, which indicated lower or higher temperature was unfavorable to biomass accumulation of microalgae with photoinhibition [8]. The microalgae in every group grew very slowly at the beginning of the culture period. After 4 days of adaptation the growth rate $S$. obliquus increased, and cells achieved the maximum biomass concentration $(0.57 \mathrm{~g} / \mathrm{l})$ at $25^{\circ} \mathrm{C}$. The microalgae at $20^{\circ} \mathrm{C}$ and $35^{\circ} \mathrm{C}$ had almost the same algae density. This result further demonstrated that higher temperature increased the growth of algae up to an optimal value, and then decreased with any further increase in temperature [13]. The decrease in growth is caused by heat stress and it leads to the inactivation of enzymes and denaturation of proteins that participate in the photosynthesis process [22]. Biochemical compositions in terms of protein, carbohydrate and lipid, were illustrated in Fig. 1B-1D. The content of protein, carbohydrate, and lipid changed slightly at different temperatures. The temperature from $20^{\circ} \mathrm{C}$ to $35^{\circ} \mathrm{C}$, the protein and carbohydrate content of S. obiquus rose firstly and then deceased, and the maximum protein and carbohydrate content was shown at $25^{\circ} \mathrm{C}$. At the temperature above $25^{\circ} \mathrm{C}$, the content of protein and carbohydrate decreased. With the increasing temperatures beyond optimum, the efficiency of protein synthesis and starch production was reduced resulting in the decrease of protein and carbohydrate content [23, 24]. When the temperatures ranged from $25^{\circ} \mathrm{C}$ to $35^{\circ} \mathrm{C}$, the lipid content rose slowly in the
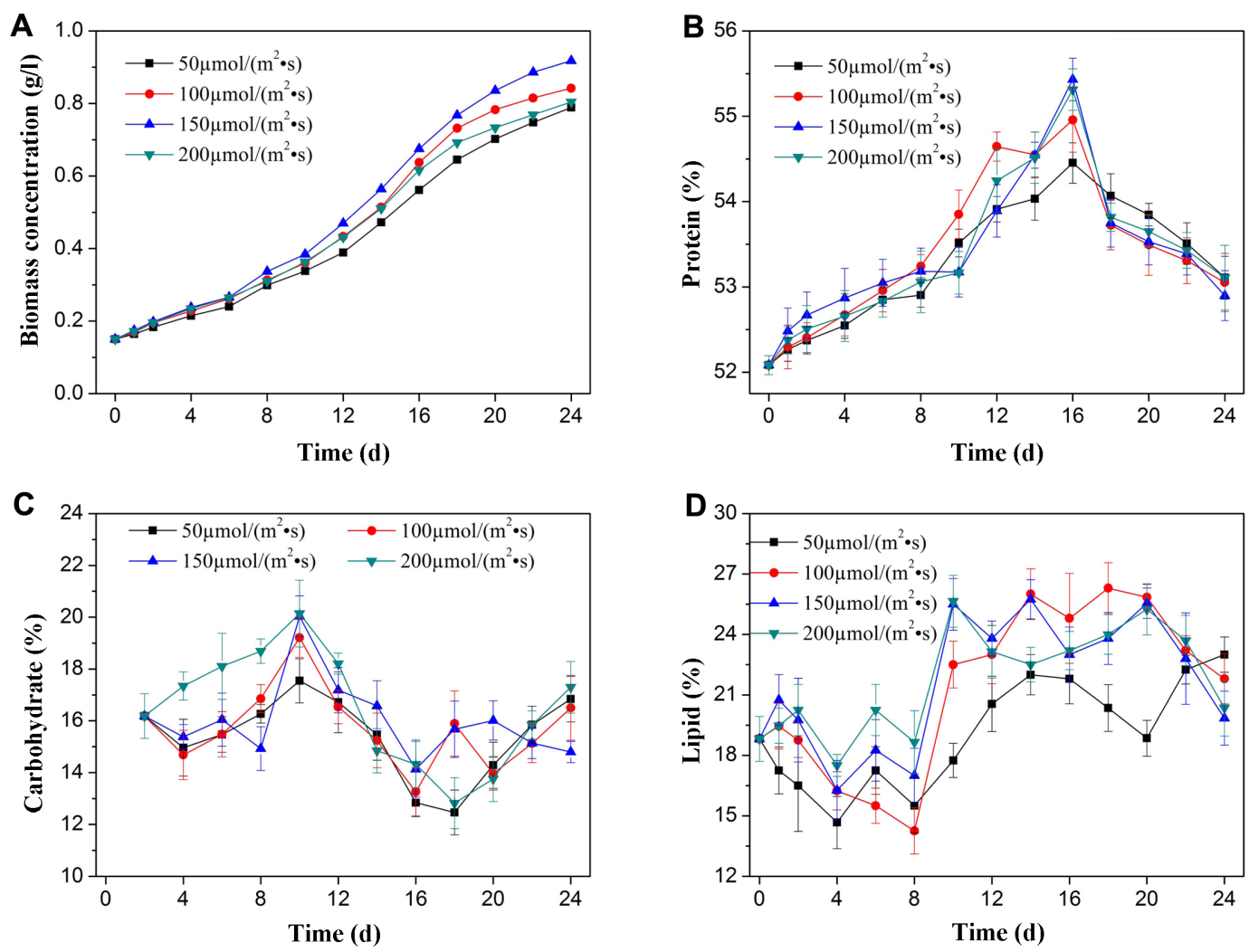

Fig. 2. The effects of light intensity on growth and biochemical compositions in S. obliquus. Biomass concentration (A), protein content (B), carbohydrate content (C), lipid content (D) under different light intensity. Error bars represent standard error. 
4 days and then declined gradually. During the exponential phase of the cultivation process, the content of lipid increased and the highest lipid content was $24 \%$ at $35^{\circ} \mathrm{C}$ which increased by $33.3 \%$. Similar influences were observed in Nannochloropsis oculata with doubled the lipid content with the growth temperature [25].

\section{Effect of light intensity on growth and biochemical com- position of S. obliquus}

The growth of S.obliquus under different light intensities was shown in Fig. 2A. It was found that the growth rate increased with rising light intensity during exponential phase. However, the algal growth dropped down when the light intensity rose above $200 \mu \mathrm{mol} /\left(\mathrm{m}^{2} \cdot \mathrm{s}\right)$. The biomass productivity trended to increase with a rising light intensity until it reached the maximum. The maximum biomass productivity of $35.10 \mathrm{mg} /(\mathrm{L} \cdot \mathrm{d})$ was obtained at a light intensity of $150 \mu \mathrm{mol} /\left(\mathrm{m}^{2} \cdot \mathrm{s}\right)$. Further rise of light intensity to $200 \mu \mathrm{mol} /\left(\mathrm{m}^{2} \cdot \mathrm{s}\right)$, led to a marked drop in biomass concentration. Three light conditions, namely light limitation, light saturation and light inhibition impacts the growth of microalgae. When the condi-
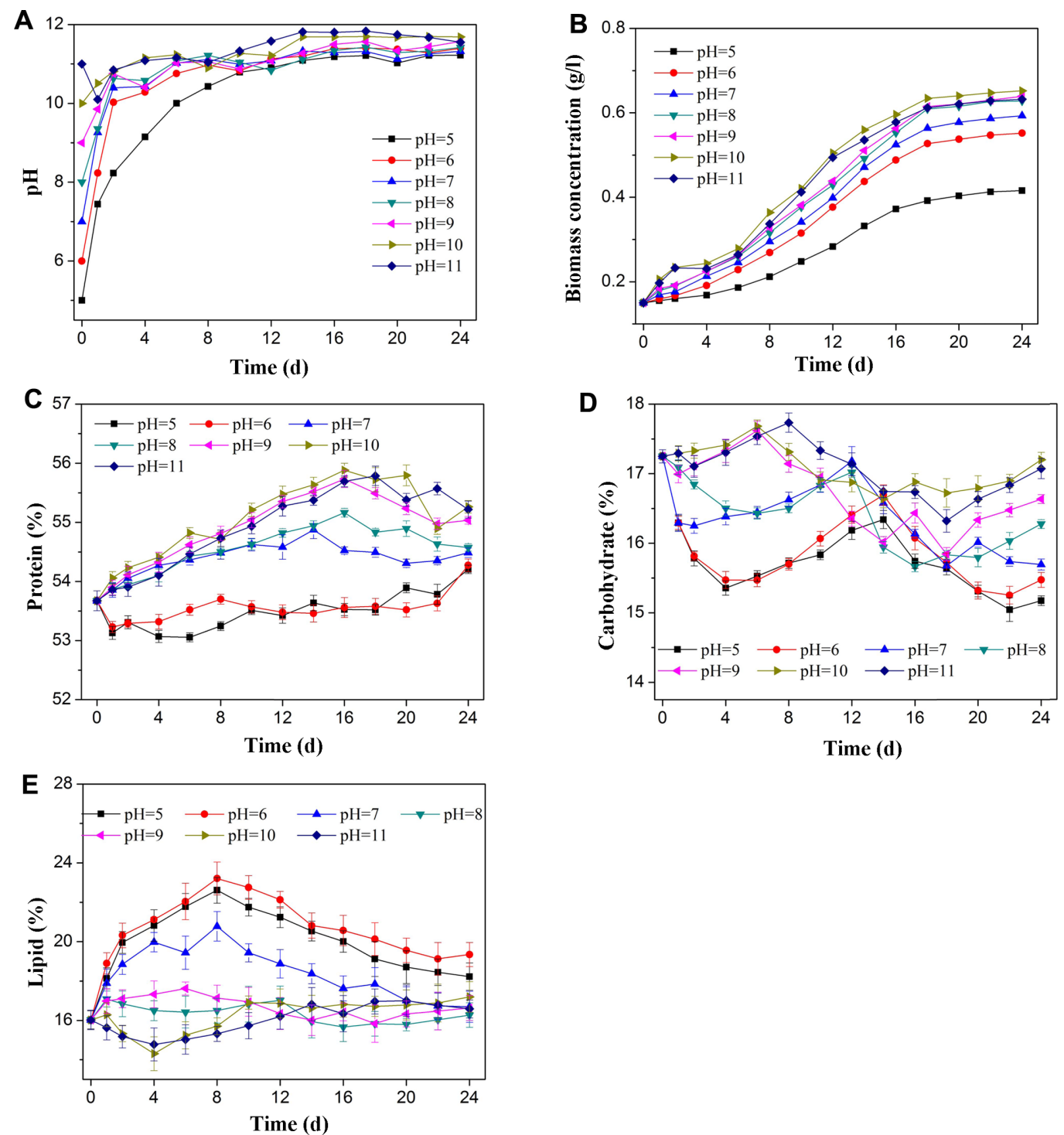

Fig. 3. Changes of $\mathrm{pH}$ and the effects of $\mathrm{pH}$ on growth and biochemical compositions in S. obliquus. Change of pH (A), Biomass concentration (B), protein content (C), carbohydrate content (D), lipid content (E) under different pH value. Error bars represent standard error. 
tion is light limiting, the growth of algae increases with rising light intensity. At light saturation, the process of photosynthesis is inhibited as the photon absorption exceeds the amount of electron turnover. When the light intensity is further increased, excessive illumination limits the growth of microalgae, which was recognized as the effect of photoinhibition resulting from the disruption of chloroplast lamellae [26-28].

Light intensity not only takes advantage of fast algal growth but influences the metabolism of cellular composition. As showed in Fig. 2B-2D, the change of cellular protein content showed a tendency of rising from initial to an exponential phrase, and during the stationary phase, the content of protein decreased. With an increase of light intensity, S. obliquus exhibited a reduction in protein content. A similar result was reported in Phaeodactylum tricornutum, in which the protein synthesis was promoted with lower light intensity of $18 \mu \mathrm{E} /$ $\left(\mathrm{m}^{2} \cdot \mathrm{s}\right)$ [29]. When light intensity was in ranges of 50$150 \mu \mathrm{mol} /\left(\mathrm{m}^{2} \cdot \mathrm{s}\right)$, the same fluctuation of carbohydrate content was observed. The light intensity had little effect on carbohydrate content the initial and stationary process, except for a slight decrease at $150 \mu \mathrm{mol} /\left(\mathrm{m}^{2} \cdot \mathrm{s}\right)$. At the light intensity of $200 \mu \mathrm{mol} /\left(\mathrm{m}^{2} \cdot \mathrm{s}\right)$, the carbohydrate content reached the highest level. The lipid content appeared to rise fluctuations ranging from 50 to 200 $\mu \mathrm{mol} /\left(\mathrm{m}^{2} \cdot \mathrm{s}\right)$ rising about $5 \%$, which increased significantly at $100-200 \mu \mathrm{mol} /\left(\mathrm{m}^{2} \cdot \mathrm{s}\right)$. In general, high light resulted in an increase in cellular lipid content [16].

\section{Change of pH value and the effect on growth and bio- chemical composition of S. obliquus}

Fig. 3A showed that the $\mathrm{pH}$ value of the culture solution turned neutral or alkaline on the first day when the condition of the cultivation for $S$. obliquus was acidic $\mathrm{pH}$, and then gradually increased and stabilized between 10 and 11. At initial $\mathrm{pH} 7$ to 9 , $\mathrm{pH}$ value increased and kept consistent after a slight decrease. The $\mathrm{pH}$ value fluctuates around 11 . When the initial $\mathrm{pH}$ was 10 to 11 , the $\mathrm{pH}$ of the culture solution was approximately 11-12. Due to the uptake of inorganic carbon by algae, $\mathrm{pH}$ can rise significantly in algal cultures [30]. It indicates that $S$. obliquus is suitable to grow under alkaline conditions. Under the treatment of different initial $\mathrm{pH}$ values, the biomass concentration was observed for the cultivation of S. obliquus (Fig. 3B). At pH 5 the algae grew slowly, and the growth rate of S. obliquus increased with increasing $\mathrm{pH}$ values up to 11 . Acidic conditions induce the inhibition of the enzyme in photosynthetic and this results in the alteration of nutrient uptake and thus affects algal growth [10]. With the increase of the initial $\mathrm{pH}$ value, the biomass concentration increased. The maximum biomass concentration was $0.65 \mathrm{~g} / \mathrm{l}$ at $\mathrm{pH} 10$.

The effect of $\mathrm{pH}$ on biochemical composition was illustrated in Fig. 3C-3E. When the pH was 5 and 6, the protein content fluctuated around $54 \%$. The protein content gradually increased at the exponential process and decreased during the stationary phase under neutral and alkaline environments. At $\mathrm{pH} 10$, the protein content reached a maximum of $55.26 \%$. The carbohydrate content significantly decreased and gradually increased at $\mathrm{pH} 5-6$. During the exponential phase, the carbohydrate content decreased by about $2 \%$. With the increase of $\mathrm{pH}$, the reduction of carbohydrate content decreased. When the $\mathrm{pH}$ was 5-7, the lipid content first increased dramatically, then slowly decreased. The content of lipid changed slightly in alkaline $\mathrm{pH}$ and varied from 15 to $17 \%$. When the $\mathrm{pH}$ was 6 , the lipid content gained the highest. Researches have demonstrated that several algae such as Chlorella zofingiensis can accumulate storage lipid under acidic condition, which was same as this study [31].

Summing up the above, the effect of several key environmental factors including temperature, light intensity and $\mathrm{pH}$ on $\mathrm{S}$. obliquus for cultivation in aim to establish optimal system was investigated. S. obliquus showed a maximum growth rate with the condition of temperature $25^{\circ} \mathrm{C}$, light intensity $150 \mu \mathrm{mol} /\left(\mathrm{m}^{2} \cdot \mathrm{s}\right)$ and $\mathrm{pH}$ value 10. Above or below the optimal value, the growth rate was inhibited. S. obliquus could quickly grow under the optimal condition, and the changes in biochemical composition differed from different conditions. Temperature and light intensity contributed to the synthesis of protein and lipid. Acidic conditions influenced the content of protein and alkaline condition mainly affected the carbohydrate and lipid content. This study of consolidated cultivation with optimal environmental factors offered essential parameters for supporting further researches with algae technology, such as an algae-wastewater system with the aim of biodiesel production and pollutant removal in photobioreactors or open ponds. 


\section{Acknowledgments}

This research was financially supported by the National Natural Science Foundation of China (No.51625804).

\section{Conflict of Interest}

The authors have no financial conflicts of interest to declare.

\section{References}

1. Abomohra AE, Eladel $\mathrm{H}$, El-Esawi M, Wang $\mathrm{S}$, Wang $\mathrm{Q}, \mathrm{He} Z$, et al. 2017. Effect of lipid-free microalgal biomass and waste glycerol on growth and lipid production of Scenedesmus obliquus: Innovative waste recycling for extraordinary lipid production. Bioresour. Technol. 249: 992-999.

2. Xin L, Hong-Ying H, Jia Y. 2010. Lipid accumulation and nutrient removal properties of a newly isolated freshwater microalga, Scenedesmus sp. LX1, growing in secondary effluent. N. Biotechnol. 27: 59-63.

3. Scott SA, Davey MP, Dennis JS, Horst I, Howe CJ, Lea-Smith DJ, et al. 2010. Biodiesel from algae: challenges and prospects. Curr. Opin. Biotechnol. 21: 277-286.

4. Demirbas A. 2011. Competitive liquid biofuels from biomass. Appl. Energy 88: 17-28.

5. Koller M, Salerno A, Tuffner P, Koinigg M, Böchzelt H, Schober S, et al. 2012. Characteristics and potential of micro algal cultivation strategies: a review. J. Clean Prod. 37: 377-388.

6. Malcata FX. 2011. Microalgae and biofuels: a promising partnership? Trends Biotechnol. 29: 542-549.

7. Behrens PW, Kyle DJ. 2010. Microalgae as a source of fatty acids. J. Food Lipids 3: 259-272.

8. Juneja A, Ceballos RM, Murthy GS. 2013. Effects of environmental factors and nutrient availability on the biochemical composition of algae for biofuels production: a review. Energies 6: 4607-4638.

9. Cabello J, Toledo-Cervantes A, Sánchez L, Revah S, Morales M. 2015. Effect of the temperature, $\mathrm{pH}$ and irradiance on the photosynthetic activity by Scenedesmus obtusiusculus under nitrogen replete and deplete conditions. Bioresour. Technol. 181: 128-135.

10. Gatamaneni BL, Orsat V, Lefsrud M. 2018. Factors affecting growth of various microalgal species. Environ. Eng. Sci. 35: https:// doi.org/10.1089/ees.2017.0521.

11. Ho SH, Chen CY, Chang JS. 20012. Chang Effect of light intensity and nitrogen starvation on $\mathrm{CO}_{2}$ fixation and lipid/carbohydrate production of an indigenous microalga Scenedesmus obliquus CNW-N. Bioresour. Technol. 113: 244-252.

12. Gris B, Morosinotto T, Giacometti GM, Bertucco A, Sforza E. 2014. Cultivation of Scenedesmus obliquus in photobioreactors: effects of light intensities and light-dark cycles on growth, productivity, and biochemical composition. Appl. Biochem. Biotechnol. 172: 2377-2389.

13. Theses and Dissertations--Biosystems and Agricultural Engineering. Available from https://uknowledge.uky.edu/bae_etds/3. Accessed April 5, 2012.

14. Martínez ME, Jiménez JM, Yousfi FE. 1999. Influence of phospho- rus concentration and temperature on growth and phosphorus uptake by the microalga Scenedesmus obliquus. Bioresour. Technol. 67: 233-240.

15. Sforza E, Gris B, de Farias Silva CE, Morosinotto T, Bertucco A. 2014. Effects of light on cultivation of Scenedesmus obliquus in batch and continuous flat plate photobioreactor. Chem. Eng. Trans. 38: 211-216.

16. Liu J, Yuan C, Hu G, Li F. 2012. Effects of light intensity on the growth and lipid accumulation of microalga Scenedesmus sp. 11-1 under nitrogen limitation. Appl. Biochem. Biotechnol. 166: 2127-2137.

17. Yang J, Li B, Zhang C, Hongxuan L, Zhou Y. 2016. pH-associated changes in induced colony formation and growth of Scenedesmus obliquus. Fundam. Appl. Limnol. 187: 241-246.

18. Allen MM. 1968. Simple conditions for growth of inicellular bluegreen algae on plates (1, 2). J. Phycol. 4: 1-4.

19. Tang D, Han W, Li P, Miao X, Zhong J. 2011. $\mathrm{CO}_{2}$ biofixation and fatty acid composition of Scenedesmus obliquus and Chlorella pyrenoidosa in response to different $\mathrm{CO}_{2}$ levels. Bioresour. Technol. 102: 3071-3076.

20. Chaplin MF, Kennedy JF. 1994. Carbohydrate analysis: a practical approach, 2nd Ed. pp. 1-41. IRL Press, New York.

21. Bligh EG, Dyer WJ. 1959. A rapid method of total lipid extraction and purification. Can. J. Biochem. Physiol. 57: 911-917.

22. Ras M, Steyer JP, Bernard O. 2013. Temperature effect on microalgae: a crucial factor for outdoor production. Rev. Environ. Sci. Biotechnol. 12: 153-164.

23. Nakamura Y, Miyach S. 1982. Effect of temperature on starch degradation in Chlorella vulgaris $11 \mathrm{~h}$ cells. Plant Cell Physiol. 23: 333-341.

24. Williams PJLB, Laurens LML. 2010. Microalgae as biodiesel \& biomass feedstocks: Review \& analysis of the biochemistry, energetics \& economics. Energy Environ. Sci. 3: 554-590.

25. Converti A, Casazza AA, Ortiz EY, Perego P, Borghi MD. 2009. Effect of temperature and nitrogen concentration on the growth and lipid content of Nannochloropsis oculata and Chlorella vulgaris for biodiesel production. Chem. Eng. Process 48: 1146-1151.

26. Chang JS, Show PL, Ling TC, et al. 2016. Photobioreactors, pp. 313-352. In LarrlRL Pressoche C, Sanroman M, Du GC, Pandey A, Curr. Dev. Biotechnol. Bioeng, 1st Ed. Elsevier, Amsterdam.

27. Pandey SS, Kumar D, Tiwari BS. 2016. Chloroplast Metabolic Engineering for Sustainable Agriculture, pp. 149-162. In Dubey S, Pandey A, Sangwan R, Curr. Dev. Biotechnol. Bioeng, 1st Ed. Elsevier, Amsterdam.

28. Fan J, Huang J, Li Y, Han F, Wang J, Li X, et al. 2012. Sequential heterotrophy-dilution-photoinduction cultivation for efficient microalgal biomass and lipid production. Bioresour. Technol. 112: 206-211.

29. Qian KX, Borowitzka MA. 1993. Light and nitrogen deficiency effects on the growth and composition of Phaeodactylum tricornutum. Appl. Biochem. Biotechnol. 38: 93-103.

30. Hansen PJ. 2002. Effect of high pH on the growth and survival of marine phytoplankton : implications for species succession. Aquat. Microb. Ecol. 28: 279-288.

31. Zhu L, Hiltunen, E, Shu Q, Zhou W, Li Z, Wang Z. 2014. Biodiesel production from algae cultivated in winter with artificial wastewater through $\mathrm{pH}$ regulation by acetic acid. Appl. Energy 218: 103-110. 